Lesson planning of the teachers and its effect on their performance in selected public elementary schools in the division of Pasig City: Basis for policy review

Rojo, Marites $\$
Emilio Aguinaldo College, Philippines (maritesv.rojo@deped.gov.ph)

Received: 30 March 2021

Available Online: 24 June 2021
Revised: 16 May 2021
DOI: $10.5861 /$ ijrse. 2021.656

Accepted: 30 May 2021

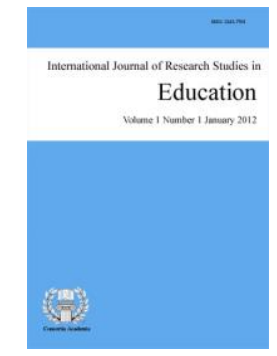

ISSN: 2243-7703

Online ISSN: 2243-7711

\title{
Abstract
}

This study determines the lesson planning skills of teachers in terms of Objectives, Content, Learning Resources, Procedures, Remarks, etc. at NAPICO Elementary School (NAES) and Manggahan Elementary School (MES) in the Division of Pasig City, as perceived by the school heads/ subject coordinator and the teachers themselves. It utilizes the descriptive research which aims to accurately and systematically describe a population, situation or phenomenon. It can answer what, when, where, when and how questions, but not why questions. Based from the findings of the study, the following conclusions have been made: 1) The teachers are equipped with necessary knowledge in lesson planning. 2) The school heads and teachers have different perception on the teaching performance in lesson planning of teachers and 3) The teachers identified minor problems in writing objectives, choosing strategies, and assessing the performance of the learners. From the conclusion drawn, the following recommendations are hereby offered: 1) Teachers may revisit their teaching strategies, teaching methods and techniques for the better outcome. 2) The teachers shall be trained in lesson planning so that they will be empowered to carry out quality instruction. 3) The problems identified shall be addressed immediately the instructional needs of the learners since they are the most important aspect of the teaching-learning process. 4) School Heads and teachers may explore and utilize different instructional strategies that considers learner's varying characteristics. 5) The proposed action plan may be adapted to capacitate teachers. 6) A similar study may be undertaken on a wider perspective considering different variables.

Keywords: assessment, content, instructional planning, learning resources, objectives 


\section{Lesson planning of the teachers and its effect on their performance in selected public elementary schools in the division of Pasig City: Basis for policy review}

\section{Introduction}

The tasks of continually looking within and improving oneself are the imperatives placed upon the teaching profession. This is so because, as the growing body of research has revealed, teacher quality is the most significant school-related influence on a child's academic performance. And classroom teachers- more than class size and previous student achievement- are the single most important factor that "adds value" to student learning. Quality teaching is the fruit of a carefully-crafted plan. A lesson plan has been thought of as the 'bible' of the teachers who underwent an interesting process called lesson or instructional planning. Instructional planning helps a teacher to visualize and forecast the future of what, why, and how of the teaching-learning process. Therefore, it is essential to ensuring the delivery of teaching and learning in schools.

One of the importance of instructional planning provides for logical sequencing and pacing of lessons, guides teachers, creates the opportunity for a higher level of questioning, and provides for various instructional objectives, and economizes cost - time and energy. The type of content that influences the planning process, textbook, and other instructional materials. Research indicates that teacher preparation or knowledge of teaching and learning, subject matter knowledge, experience, and the combined set of qualifications measured by teacher licensure are all leading factors in teacher effectiveness (Darling-Hammond, 2006). On the other hand, the teachers' attitudes, beliefs, orientations, and teachers' social background are components of Instructional Planning, according to Bermari et al. (2011). Therefore, effective instructional planning is not the only skill a teacher must possess to be considered an expert. However, it is very difficult to imagine a teacher experiencing high levels of learning for students if planning practices are ineffective or nonexistent. Therefore, learning how to plan for effective instruction is a critical part of the elementary school teacher's work daily.

Various literature has proven that instructional planning is an essential tool in teaching. For example, in Dick and Reiser (1996), instructional planning is essential to successful teaching and learning. Instructional planning is the process of determining what learning opportunities students in School will have by planning "the content of instruction, selecting teaching materials, designing the learning activities and grouping methods, and deciding on the pacing and allocation of the instructional time" (Virginia Department of Education, 2016). According to Airasian (1994), planning is a vital step in the instructional process. It involves identifying expectations for learners, choosing the materials, and organizing sequential activities to help learners reach those expectations.

Instructional planning guarantees that teaching and learning are the central focus of classroom activity. Furthermore, it helps ensure that the time spent inside the classroom is maximized for instruction, is responsive to learners' needs, and therefore communicates expectations of achievement to learners (Stronge, 2007). In cognizance of this need, the Department of Education (DepEd) of the Philippines acknowledges that planning lessons are fundamental to ensuring the delivery of teaching and learning in schools. Thus, DepEd Order No. 42 series of 2016, which underscores the implementation of the Republic Act (R.A.) No. 10533 or the Enhanced Basic Education Act of 2013 emphasizes this move in its Policy Guidelines on Daily Lesson Preparation for the K to 12 Basic Education Program.

Daily lesson preparation also encourages reflective practice since it requires teachers to think about and reflect on their instructional practices daily. Article IV, Section 2 of the Code of Ethics for Professional Teachers adopted in 1997 through Board Resolution No. 435 by the Board of Professional Teachers states that "every teacher shall uphold the highest standards of quality education, shall make the best preparations for the career of teaching, and shall be at his best at all times in the practice of his profession." Therefore, this policy is meant to support teachers in upholding quality education standards by affirming the importance of instructional planning 
Lesson planning of the teachers and its effect on their performance in selected public elementary schools

through Daily Lesson Log (DLL) or Detailed Lesson Plan (DLP) preparation. These guidelines ultimately aim to assist teachers in effectively managing instruction and managing the performance of one of their core functions, which is to facilitate learning inside their classrooms. This study sought to gather information and insight from teachers who demonstrated expertise in realizing high levels of student learning. In addition, the specific planning decisions they made and activities they engaged in while planning, including the difficulties and challenges, were studied.

\subsection{Significance of the study}

This study will benefit the following stakeholders:

Department of Education. This study could be a base reference in enhancing the policy guidelines on Daily Lesson Preparation for the K to 12 Basic Education Program. Furthermore, this could also be applied to provide solutions to teacher difficulties in preparing for instructions.

Public Elementary Schools. This study provided a big picture of the teachers' methods and practices that could influence their academic decisions in instructional planning.

Curriculum Planners. This study could persuade and encourage the curriculum planners to formulate and implement an effective curriculum to cope with the School's academic requirements.

Principals. Since delivery of lesson by teachers were of paramount importance should effective student learning take place in the classroom; principals ensure that best practices and time-tested strategies/ techniques in instructions be implemented more efficiently and effectively.

Head Teachers. Being the academic supervisors, they are expected to oversee the teachers' full implementation, especially in terms of instructional planning. Therefore, this study will be of great help for the head-teachers as the study offers the strengths and weaknesses of the teachers in planning their lessons and ensuring that student learning is taking place.

Teachers. This study was used as a reference for the formulation of various methods and approaches in helping the students acquire learning effectively. The study can elevate the quality standards of teachers because of the occurrences of different strategies in instructional planning.

Students. The appropriateness of assessment styles leads to the uncovering of the strategies in lesson planning. Therefore, this study provided vital information for the teachers in planning for the lessons effectively and efficiently, and thus, benefit the students.

Future Researchers. This study helped future researchers determine the knowledge and capacity of teachers in lesson planning and the strategies that they can provide through the teaching process.

\section{Methodology}

This study made use of the descriptive research method. The researcher determined the instructional planning competence of the Teachers at NAPICO Elementary School (NES) and Manggahan Elementary School (MES). Descriptive research is a study designed to depict the participants in an accurate way. More simply put, descriptive research was all about describing people who take part in the study. There were three ways a researcher can go about doing a descriptive research project. They were: (1) Observational, defined as a method of viewing and recording the participants, (2) Case study, defined as an in-depth study of an individual or group of individuals; and (3) Survey, which uses the research instrument containing the assessment of the level of instructional planning competence of the teachers. In this study, the survey method was used to draw information and data about the study variables.

This study used the purposive sampling technique. A purposive sample is a non-probability sample selected 
Rojo, M.

based on the characteristics of a population and the study's objective. This type of sampling could be very useful when you need to reach a targeted sample quickly, and sampling for proportionality was not the main concern. In addition, the purposive sampling method may prove effective when only limited numbers of people can serve as primary data sources due to the nature of research design and aims and objectives. The questionnaire was a researcher-made instrument based on the policy guidelines of the DepEd Order No. 42 series of 2016. The first part of the research instrument determined the profile of the two groups of respondents as to age, sex, and position. The second part contained the six components- Objectives, Content, Learning Resources, Procedures, Remarks, Reflection, Subject Matter, Strategies, and Assessment with ten indicators to determine the teachers' level of instructional competence. Five experts in the field of research and the members of the review validated the research instruments. The researcher welcomed the suggestions and made necessary revisions to make the said instrument valid.

The administration of the research instrument started in the third week of July 2019. Each instrument was administered to all target respondents during their class or office breaks in their respective locales. The researcher employed research assistants to gather all survey returns within two weeks. Each respondent was given ample time to answer the research instrument. The said questionnaire may be answered within a minimum time of five minutes. However, due to the voluminous questions posed in the instrument, a number of the respondents may request more time to answer the same. The research assistant left the questionnaires to the respondents who required more time, but they were collected at their convenience. The survey returns were gathered within seven (7) days. The researcher employed one mode of data collection technique which is through personal administration. The researcher/ assistants took no pains in collecting the fully-filled data from the respondents. The researcher reviewed the survey returns to check the completeness of the required data. Then, the researcher tallied and coded the responses of the respondents using Microsoft Excel. The Statistical Program for Social Science or SPSS version 21.0 was used to treat the data using appropriate statistical tools. The researcher employed a statistician to never go wrong in providing the necessary statistical treatment of the data and guided her in interpreting/ analyzing the same.

\section{Findings and discussion}

This includes the presentation and interpretation of data followed by the sequence of the specific problem stated in the study. What is the teaching performance in lesson planning of the teachers during the first semester, as assessed by the two groups of respondents concerning the objectives?

\section{Table 1}

Teaching performance in lesson planning of the teachers during the first semester: Objectives

\begin{tabular}{|c|c|c|c|c|c|c|}
\hline \multirow{2}{*}{ Objectives } & \multicolumn{2}{|c|}{ School Heads } & \multicolumn{2}{|c|}{ Teachers } & \multicolumn{2}{|c|}{ Overall } \\
\hline & Mean & VI & Mean & VI & Mean & VI \\
\hline 1. Ensured the delivery of teaching and learning in schools. & 3.67 & $\mathrm{HC}$ & 3.64 & $\mathrm{HC}$ & 3.65 & $\mathrm{HC}$ \\
\hline 2. aimed to support teachers in organizing and managing their classes. & 3.90 & $\mathrm{HC}$ & 3.62 & $\mathrm{HC}$ & 3.66 & $\mathrm{HC}$ \\
\hline 3. affirmed the role of elementary teachers as a facilitator of learning. & 3.71 & $\mathrm{HC}$ & 3.66 & $\mathrm{HC}$ & 3.67 & $\mathrm{HC}$ \\
\hline $\begin{array}{l}\text { 4. provided teachers with an opportunity for reflection on what learners } \\
\text { need to learn. }\end{array}$ & 3.71 & $\mathrm{HC}$ & 3.52 & $\mathrm{HC}$ & 3.55 & $\mathrm{HC}$ \\
\hline 5. facilitated the students' learning process. & 3.71 & $\mathrm{HC}$ & 3.67 & $\mathrm{HC}$ & 3.67 & $\mathrm{HC}$ \\
\hline 6. aimed to empower teachers to carry out quality instruction. & 3.71 & $\mathrm{HC}$ & 3.55 & $\mathrm{HC}$ & 3.57 & $\mathrm{HC}$ \\
\hline 7. recognized the diversity of learners inside the classroom. & 3.62 & $\mathrm{HC}$ & 3.83 & $\mathrm{HC}$ & 3.80 & $\mathrm{HC}$ \\
\hline 8. committed to learners' success. & 3.76 & $\mathrm{HC}$ & 3.75 & $\mathrm{HC}$ & 3.75 & $\mathrm{HC}$ \\
\hline 9. allowed the use of varied instructional strategies. & 3.81 & $\mathrm{HC}$ & 3.69 & $\mathrm{HC}$ & 3.71 & $\mathrm{HC}$ \\
\hline 10. enabled the teacher to guide, mentor, and support learners' & 3.77 & $\mathrm{HC}$ & 3.65 & $\mathrm{HC}$ & 3.67 & $\mathrm{HC}$ \\
\hline Composite Mean & 3.74 & $\mathrm{HC}$ & 3.64 & $\mathrm{HC}$ & 3.66 & $\mathrm{HC}$ \\
\hline
\end{tabular}

Table 1 on the next page illustrated the teaching performance in lesson planning of the teachers during the first semester, as assessed by the two groups of respondents in terms of objectives with composite means of 3.74 and 3.64 for school heads and teachers, respectively verbally. Interpreted as "Highly Competent." A total of 3.66 mean 
Lesson planning of the teachers and its effect on their performance in selected public elementary schools were obtained verbally interpreted as "Highly Competent." School Heads were "Highly Competent" in aiming to support teachers in organizing and managing their classes $(\bar{x}=3.90)$, allowing the use of varied instructional strategies $(\bar{x}=3.81)$, and committing to learners' success $(\bar{x}=3.76)$. Teachers, on the other hand, were "Highly Competent" in recognizing the diversity of learners inside the classroom $(\overline{\mathrm{x}}=3.83)$, committing to learners' success $(\overline{\mathrm{x}}=3.75)$, and allowing the use of varied instructional strategies $(\overline{\mathrm{x}}=3.69)$.

Table 2

Teaching performance in lesson planning of the teachers during the first semester: Content

\begin{tabular}{|c|c|c|c|c|c|c|}
\hline \multirow{2}{*}{ Content } & \multicolumn{2}{|c|}{ School Heads } & \multicolumn{2}{|c|}{ Teachers } & \multicolumn{2}{|c|}{ Overall } \\
\hline & Mean & VI & Mean & VI & Mean & VI \\
\hline 1. challenged relevant topics/lessons. & 3.62 & $\mathrm{HC}$ & 3.54 & $\mathrm{HC}$ & 3.55 & $\mathrm{HC}$ \\
\hline $\begin{array}{l}\text { 2. connected to the construction of new learnings to make decisions and solve } \\
\text { problems. }\end{array}$ & 3.67 & $\mathrm{HC}$ & 3.55 & $\mathrm{HC}$ & 3.56 & $\mathrm{HC}$ \\
\hline 3. facilitated opportunities for students to be metacognitive. & 3.62 & $\mathrm{HC}$ & 3.48 & $\mathrm{C}$ & 3.50 & $\mathrm{C}$ \\
\hline 4. used meaningful and authentic learning content in a real-world context. & 3.81 & $\mathrm{HC}$ & 3.60 & $\mathrm{HC}$ & 3.63 & $\mathrm{HC}$ \\
\hline 5. facilitated time for students to learn collaboratively. & 3.71 & $\mathrm{HC}$ & 3.60 & $\mathrm{HC}$ & 3.61 & $\mathrm{HC}$ \\
\hline $\begin{array}{l}\text { 6. engaged students in experiential learning that is authentic, holistic, and } \\
\text { challenging. }\end{array}$ & 3.86 & $\mathrm{HC}$ & 3.52 & $\mathrm{HC}$ & 3.57 & $\mathrm{HC}$ \\
\hline 7. empowered students to use their prior knowledge to construct new learning. & 3.71 & $\mathrm{HC}$ & 3.57 & $\mathrm{HC}$ & 3.59 & $\mathrm{HC}$ \\
\hline 8. covered a wide range of topics. & 3.52 & $\mathrm{HC}$ & 3.39 & $\mathrm{C}$ & 3.41 & $\mathrm{C}$ \\
\hline $\begin{array}{l}\text { 9. employed a variety of interactive learning techniques through the content } \\
\text { application. }\end{array}$ & 3.62 & $\mathrm{HC}$ & 3.45 & $\mathrm{HC}$ & 3.48 & $\mathrm{C}$ \\
\hline 10. supported or improved students' performance. & 3.76 & $\mathrm{HC}$ & 3.61 & $\mathrm{HC}$ & 3.63 & $\mathrm{HC}$ \\
\hline Composite Mean & 3.69 & $\mathrm{HC}$ & 3.53 & $\mathrm{HC}$ & 3.55 & $\mathrm{HC}$ \\
\hline
\end{tabular}

Table 2 on the next page shows the teaching performance in lesson planning of the teachers during the first semester, as assessed by the two groups of respondents in terms of content with composite means of 3.69 for school heads and 3.53 for teachers with a total of 3.55 which were all interpreted as "Highly Competent." School Heads were "Highly Competent" in challenging relevant topics/lessons ( $\overline{\mathrm{x}}=3.86$ ), connecting to the construction of new learning to make decisions and solve problems $(\bar{x}=3.81)$, and facilitates opportunities for students to be metacognitive. $(\bar{x}=3.76)$ while teachers are "Highly Competent" in supporting or improving students' performance $(\bar{x}=3.61)$, using meaningful and authentic learning content in a real-world context $(\bar{x}=3.60)$, and facilitating time for students to learn collaboratively $(\bar{x}=3.60)$.

\section{Table 3}

Teaching performance in lesson planning of the teachers during the first semester: Learning resources

\begin{tabular}{|c|c|c|c|c|c|c|}
\hline \multirow{2}{*}{ Learning Resources } & \multicolumn{2}{|c|}{ School Heads } & \multicolumn{2}{|c|}{ Teachers } & \multicolumn{2}{|c|}{ Overall } \\
\hline & Mean & VI & Mean & VI & Mean & VI \\
\hline $\begin{array}{l}\text { 1. logged the references and other learning resources that he/she used for the } \\
\text { lesson }\end{array}$ & 3.62 & $\mathrm{HC}$ & 3.52 & $\mathrm{HC}$ & 3.51 & $\mathrm{HC}$ \\
\hline $\begin{array}{l}\text { 2. included the particular pages of the teachers' guides, learners' manual, } \\
\text { textbook, etc. }\end{array}$ & 3.71 & $\mathrm{HC}$ & 3.59 & $\mathrm{HC}$ & 3.61 & $\mathrm{HC}$ \\
\hline $\begin{array}{l}\text { 3. included the supplies, equipment, tools, and other non-print materials } \\
\text { needed for activities before, during, and after the lesson. }\end{array}$ & 3.57 & $\mathrm{HC}$ & 3.45 & $\mathrm{C}$ & 3.46 & $\mathrm{C}$ \\
\hline 4. covered the breadth but not the depth of a subject. & 3.57 & $\mathrm{HC}$ & 3.33 & $\mathrm{C}$ & 3.36 & $\mathrm{C}$ \\
\hline $\begin{array}{l}\text { 5. provided a rich array of innovative educational materials for classroom } \\
\text { instruction. }\end{array}$ & 3.57 & $\mathrm{HC}$ & 3.36 & $\mathrm{C}$ & 3.39 & $\mathrm{C}$ \\
\hline 6. determine what content will be effective for learners. & 3.71 & $\mathrm{HC}$ & 3.56 & $\mathrm{HC}$ & 3.58 & $\mathrm{HC}$ \\
\hline 7. helped differentiate instruction. & 3.76 & $\mathrm{HC}$ & 3.61 & $\mathrm{HC}$ & 3.63 & $\mathrm{HC}$ \\
\hline $\begin{array}{l}\text { 8. included qualitative assessment and contains comprehensive teacher } \\
\text { guides. }\end{array}$ & 3.62 & $\mathrm{HC}$ & 3.68 & $\mathrm{HC}$ & 3.67 & $\mathrm{HC}$ \\
\hline $\begin{array}{l}\text { 9. adhere to quality content and design standards as well as providing a } \\
\text { meaningful education experience. }\end{array}$ & 3.62 & $\mathrm{HC}$ & 3.44 & $\mathrm{C}$ & 3.46 & $\mathrm{C}$ \\
\hline $\begin{array}{l}\text { 10. engaged today's students and teachers as well as aligned to state, district, } \\
\text { and curriculum standards }\end{array}$ & 3.67 & $\mathrm{HC}$ & 3.49 & $\mathrm{C}$ & 3.52 & $\mathrm{HC}$ \\
\hline $\begin{array}{ll}\text { Composite Mean } \\
\end{array}$ & 3.66 & $\mathrm{HC}$ & 3.49 & $\mathrm{C}$ & 3.51 & $\mathrm{HC}$ \\
\hline
\end{tabular}

Table 3 on the previous page presents the teaching performance in lesson planning of the teachers during the first semester, as assessed by the two groups of respondents in terms of a learning resource with composite 
Rojo, M.

means of 3.66 for heads and 3.49 for teachers with a total of 3.51 which were all interpreted as "Highly Competent." School Heads were "Highly Competent" in the log the references and other learning resources that he/she used for the lesson ( $\bar{x}=3.63)$. In addition, include the particular pages of the teachers' guides, learners' manual, textbook, etc. $(\bar{x}=3.63)$; include the supplies, equipment, tools, and other non-print materials needed for activities before, during, and after the lesson $(\overline{\mathrm{x}}=3.61)$. Teachers, on the other hand, are "Competent" in including the qualitative assessment that contains comprehensive teacher guides $(\bar{x}=3.68)$; helping differentiate instruction $(\bar{x}=3.61)$; and including the particular pages of the teachers' guides, learners' manual, textbook, etc. $(\bar{x}=3.59)$.

\section{Table 4}

Teaching performance in lesson planning of the teachers during the first semester: Procedures

\begin{tabular}{|c|c|c|c|c|c|c|}
\hline \multirow{2}{*}{ Procedures } & \multicolumn{2}{|c|}{ School Heads } & \multicolumn{2}{|c|}{ Teachers } & \multicolumn{2}{|c|}{ Overall } \\
\hline & Mean & VI & Mean & VI & Mean & VI \\
\hline $\begin{array}{l}\text { 1. created organized and cohesive to assist students in making connections } \\
\text { to key concepts. }\end{array}$ & 3.71 & $\mathrm{HC}$ & 3.40 & $\mathrm{HC}$ & 3.44 & $\mathrm{C}$ \\
\hline 2. reviewed the previous lesson/s and presented a new lesson. & 3.81 & $\mathrm{HC}$ & 3.60 & $\mathrm{HC}$ & 3.63 & $\mathrm{HC}$ \\
\hline 3. motivated learners to learn a new lesson. & 3.81 & $\mathrm{HC}$ & 3.95 & $\mathrm{HC}$ & 3.93 & $\mathrm{HC}$ \\
\hline 4. prepared good questions for the lesson part. & 3.76 & $\mathrm{HC}$ & 3.67 & $\mathrm{HC}$ & 3.68 & $\mathrm{HC}$ \\
\hline 5. deepened the lesson and show learner's new ways of applying to learn. & 3.71 & $\mathrm{HC}$ & 3.53 & $\mathrm{HC}$ & 3.56 & $\mathrm{HC}$ \\
\hline $\begin{array}{l}\text { 6. demonstrated students' learnings through assessable activities such as } \\
\text { quizzes, worksheets, seatwork, and games. }\end{array}$ & 3.71 & $\mathrm{HC}$ & 3.50 & $\mathrm{C}$ & 3.53 & $\mathrm{HC}$ \\
\hline 7. found the practical application of concepts and skills. & 3.67 & $\mathrm{HC}$ & 3.41 & $\mathrm{C}$ & 3.44 & $\mathrm{C}$ \\
\hline $\begin{array}{l}\text { 8. helped students crystalize their learning so they can declare knowledge } \\
\text { and demonstrate their skills. }\end{array}$ & 3.67 & $\mathrm{HC}$ & 3.39 & $\mathrm{C}$ & 3.43 & $\mathrm{C}$ \\
\hline 9. provided children with enrichment or remedial activities. & 3.81 & $\mathrm{HC}$ & 3.52 & $\mathrm{HC}$ & 3.56 & $\mathrm{HC}$ \\
\hline 10. provided extra time for additional teaching activities to these learners & 3.57 & $\mathrm{HC}$ & 3.40 & $\mathrm{C}$ & 3.42 & $\mathrm{C}$ \\
\hline Composite Mean & 3.72 & $\mathrm{HC}$ & 3.52 & $\mathrm{HC}$ & 3.55 & $\mathrm{HC}$ \\
\hline
\end{tabular}

Table 4 on the next page manifests the teaching performance in lesson planning of the teachers during the first semester. As assessed by the two groups of respondents in terms of procedures wherein school heads have a composite mean of 3.72, teachers with 3.52 and a total of 3.55 are verbally interpreted as "Highly Competent." School Heads were "Highly Competent" in creating organized and cohesive to assist students in making connections to key concepts $(\overline{\mathrm{x}}=3.71)$, reviewing the previous lesson/s and presents new lesson $(\overline{\mathrm{x}}=3.81)$, and motivate learners to learn a new lesson $(\bar{x}=3.81)$. In addition, teachers are also "Highly Competent" in motivating learners to learn the new lesson $(\bar{x}=(\bar{x}=3.95)$; prepare a good question for the lesson part $(\bar{x}=3.67)$; review the previous lesson/s and presents new lesson $(\overline{\mathrm{x}}=3.60)$.

\section{Table 5}

Teaching performance in lesson planning of the teachers during the first semester: Remarks

\begin{tabular}{|c|c|c|c|c|c|c|}
\hline \multirow{2}{*}{ Remarks } & \multicolumn{2}{|c|}{ School Heads } & \multicolumn{2}{|c|}{ Teachers } & \multicolumn{2}{|c|}{ Overall } \\
\hline & Mean & VI & Mean & VI & Mean & VI \\
\hline $\begin{array}{l}\text { 1. indicated the continuation of the lesson plan to the following } \\
\text { day in cases of re-teaching or lack of time. }\end{array}$ & 2.10 & MC & 1.94 & MC & 1.96 & $\mathrm{MC}$ \\
\hline $\begin{array}{l}\text { 2. indicated transfer of lesson to the following day in cases of } \\
\text { class suspension etc. }\end{array}$ & 2.00 & MC & 1.80 & MC & 1.83 & $\mathrm{MC}$ \\
\hline 3. explained how he/she develops the plan. & 1.95 & $\mathrm{MC}$ & 1.95 & MC & 1.95 & MC \\
\hline 4. included students' comments and reactions. & 2.10 & $\mathrm{MC}$ & 2.00 & $\mathrm{MC}$ & 2.02 & $\mathrm{MC}$ \\
\hline $\begin{array}{l}\text { 5. discuss some of the instructional strategies and classroom } \\
\text { management issues related to the lesson. }\end{array}$ & 2.14 & $\mathrm{MC}$ & 1.99 & $\mathrm{MC}$ & 2.01 & $\mathrm{MC}$ \\
\hline 6. extended some ideas of extra credits. & 2.14 & MC & 1.98 & $\mathrm{MC}$ & 2.00 & MC \\
\hline 7. provided modifications to the instructional planning. & 2.00 & MC & 1.95 & $\mathrm{MC}$ & 1.95 & MC \\
\hline $\begin{array}{l}\text { 8. included anything that you should know about instructional } \\
\text { planning. }\end{array}$ & 2.10 & $\mathrm{MC}$ & 1.95 & $\mathrm{MC}$ & 1.97 & $\mathrm{MC}$ \\
\hline 9. considered different scheduling constraints. & 2.24 & $\mathrm{MC}$ & 2.05 & $\mathrm{MC}$ & 2.07 & MC \\
\hline 10. explained time requirements as specifically as possible. & 2.24 & MC & 2.09 & MC & 2.11 & MC \\
\hline Composite Mean & 2.10 & MC & 1.97 & $\mathrm{MC}$ & 1.99 & MC \\
\hline
\end{tabular}


Lesson planning of the teachers and its effect on their performance in selected public elementary schools

Table 5 on the previous page presents the teaching performance in lesson planning of the teachers during the first semester, as assessed by the two groups of respondents in terms of remarks revealed that the School Head and teachers got the composite mean of 2.10 and 1.97 , respectively with a total of 1.99 with the verbal interpretation of "Moderately Competent." This indicates that heads were "Moderately Competent" in considering different scheduling constraints $(\overline{\mathrm{x}}=2.24)$, explaining time requirements as specifically as possible $(\bar{x}=2.24)$, and discussing some of the instructional strategies and classroom management issues related to the lesson $(\bar{x}=2.14)$. Teachers were also moderately competent but in explaining time requirements as specifically as possible $(\bar{x}=2.09)$, considering different scheduling constraints $(\bar{x}=2.05$; and including students' comments and reactions $(\overline{\mathrm{x}}=2.01)$.

\section{Table 6}

Teaching performance in lesson planning of the teachers during the first semester: Reflection

\begin{tabular}{|c|c|c|c|c|c|c|}
\hline \multirow{2}{*}{ Reflection } & \multicolumn{2}{|c|}{ School Heads } & \multicolumn{2}{|c|}{ Teachers } & \multicolumn{2}{|c|}{ Overall } \\
\hline & Mean & VI & Mean & VI & Mean & VI \\
\hline 1. reflected on the student's thinking. & 3.19 & $\mathrm{C}$ & 3.34 & $\mathrm{C}$ & 3.32 & $\mathrm{C}$ \\
\hline 2. required teachers to assess their effectiveness. & 3.24 & $\mathrm{C}$ & 3.27 & $\mathrm{C}$ & 3.27 & $\mathrm{C}$ \\
\hline $\begin{array}{l}\text { 3. provided notes on the number of learners who earned certain points } \\
\text { in the evaluations. }\end{array}$ & 3.29 & $\mathrm{C}$ & 3.33 & $\mathrm{C}$ & 3.33 & $\mathrm{C}$ \\
\hline 4. required additional activities for remediation. & 3.29 & $\mathrm{C}$ & 3.25 & $\mathrm{C}$ & 3.25 & $\mathrm{C}$ \\
\hline $\begin{array}{l}\text { 5. helped solve some difficulties encountered by teachers in their } \\
\text { teaching strategies or methods. }\end{array}$ & 3.24 & $\mathrm{C}$ & 3.23 & $\mathrm{C}$ & 3.23 & $\mathrm{C}$ \\
\hline 6. helped the teachers become better in terms of instructional planning. & 3.29 & $\mathrm{C}$ & 3.28 & $\mathrm{C}$ & 3.28 & $\mathrm{C}$ \\
\hline $\begin{array}{l}\text { 7. included an evaluative note on the lesson plan that will help the } \\
\text { teachers improve. }\end{array}$ & 3.29 & $\mathrm{C}$ & 3.14 & $\mathrm{C}$ & 3.16 & $\mathrm{C}$ \\
\hline 8. showed how clear the teachers' presentation is. & 3.24 & $\mathrm{C}$ & 3.20 & $\mathrm{C}$ & 3.20 & $\mathrm{C}$ \\
\hline 9. required the teachers to think back on the lesson. & 3.33 & $\mathrm{C}$ & 3.20 & $\mathrm{C}$ & 3.22 & $\mathrm{C}$ \\
\hline 10. determined what went well in the lesson. & 3.38 & $\mathrm{C}$ & 3.29 & $\mathrm{C}$ & 3.30 & $\mathrm{C}$ \\
\hline Composite Mean & 3.28 & $\mathrm{C}$ & 3.25 & $\mathrm{C}$ & 3.26 & $\mathrm{C}$ \\
\hline
\end{tabular}

Table 6 on the next page presented the teaching performance in lesson planning of the teachers during the first semester, as assessed by the two groups of respondents in terms of reflection were, the school heads got the composite mean of 3.28 and 3.25 for teachers with a total of 3.26 verbal interpreted as "Competent." School heads were "Competent," determining what went well on the lesson $(\bar{x}=3.38)$, requiring the teachers to think back on the lesson $(\bar{x}=3.33)$, and providing notes on the number of learners who earned certain points in the evaluations $(\bar{x}=3.29)$. Also, teachers were "Competent" in reflecting on the student's thinking $(\bar{x}=3.34)$; providing notes on the number of learners who earned certain points in the evaluations $(\overline{\mathrm{x}}=3.33)$; and determine what went well on the lesson $(\bar{x}=3.29)$.

Table 7

Composite table on the teaching performance in lesson planning of the teachers during the first semester

\begin{tabular}{|c|c|c|c|c|c|c|c|}
\hline \multirow{2}{*}{\multicolumn{2}{|c|}{ Variables }} & \multicolumn{2}{|c|}{ School Heads } & \multicolumn{2}{|c|}{ Teachers } & \multicolumn{2}{|c|}{ Overall } \\
\hline & & Mean & VI & Mean & VI & Mean & VI \\
\hline 1. Objectives & & 3.74 & $\mathrm{HC}$ & 3.64 & $\mathrm{HC}$ & 3.66 & $\mathrm{HC}$ \\
\hline 2. Contents & & 3.69 & $\mathrm{HC}$ & 3.53 & $\mathrm{HC}$ & 3.55 & $\mathrm{HC}$ \\
\hline 3. Learning Resources & & 3.66 & $\mathrm{HC}$ & 3.49 & $\mathrm{C}$ & 3.51 & $\mathrm{HC}$ \\
\hline 4. Procedures & & 3.72 & $\mathrm{HC}$ & 3.52 & $\mathrm{HC}$ & 3.55 & $\mathrm{HC}$ \\
\hline 5. Remarks & & 2.10 & MC & 1.97 & $\mathrm{MC}$ & 1.99 & MC \\
\hline 6. Reflection & & 3.28 & $\mathrm{C}$ & 3.25 & $\mathrm{C}$ & 3.26 & $\mathrm{C}$ \\
\hline & Overall Composite Mean & 3.37 & $\mathrm{C}$ & 3.23 & $\mathrm{C}$ & 3.25 & $\mathrm{C}$ \\
\hline
\end{tabular}

Table 7 shows the composite table on the teaching performance in lesson planning of the teachers during the first semester as assessed by the two groups of respondents concerning different variables. The table revealed that the overall composite means obtained were 3.37 and 3.23 for school heads and teachers, respectively, both interpreted as "Competent," with the total of 3.25 verbally interpreted as "Competent." 
Rojo, M.

Table 8

Significant difference between the assessments of the two groups of respondents on the teaching performance

\begin{tabular}{|c|c|c|c|c|c|c|c|}
\hline Variables & Respondents & Mean & SD & F-Value & Sig. & Decision on Ho & VI \\
\hline \multirow[t]{2}{*}{ Objectives } & School Heads & 3.74 & 0.08 & 2.10 & 0.04 & Rejected & $\mathrm{S}$ \\
\hline & Teachers & 3.66 & 0.09 & & & & \\
\hline \multirow[t]{2}{*}{ Contents } & School Heads & 3.69 & 0.10 & 4.03 & 0.00 & Rejected & $\mathrm{S}$ \\
\hline & Teachers & 3.53 & 0.07 & & & & \\
\hline Learning & School Heads & 3.64 & 0.07 & 3.38 & 0.00 & Rejected & S \\
\hline Resources & Teachers & 3.50 & 0.11 & & & & \\
\hline \multirow[t]{2}{*}{ Procedures } & School Heads & 3.72 & 0.08 & 3.11 & 0.00 & Rejected & $S$ \\
\hline & Teachers & 3.54 & 0.17 & & & & \\
\hline \multirow[t]{2}{*}{ Remarks } & School Heads & 2.10 & 0.10 & 3.34 & 0.00 & Rejected & S \\
\hline & Teachers & 1.97 & 0.08 & & & & \\
\hline \multirow[t]{2}{*}{ Reflection } & School Heads & 3.28 & 0.05 & 0.96 & 0.35 & Accepted & NS \\
\hline & Teachers & 3.25 & 0.06 & & & & \\
\hline
\end{tabular}

Table 8 revealed the significant difference between the assessments of the two groups of respondents on the teaching performance in lesson planning of the teachers. In terms of "Objectives," School heads obtained the mean of 3.74 with a standard deviation of 0.08 while teachers got the mean of 3.66 with a standard deviation of 0.09 . The F-value was 2.10, while the significance value was 0.04 , which does not exceed the 0.05 level of significance. Thus, the null hypothesis states that there is no significant difference between the assessment of the two groups of respondents on the teaching performance in lesson planning of teachers was Rejected and found to be significant.

In terms of "Contents," School heads obtained the mean of 3.69 with a standard deviation of 0.10 while teachers got the mean of 3.53 with a standard deviation of 0.07 . Therefore, the F-value was 4.03 while the significance value was 0.00 , which does not exceed the 0.05 level of significance; thus, the null hypothesis was rejected and found to be significant. In terms of "Learning Resources," School heads obtained the mean of 3.64 with a standard deviation of 0.07 , while teachers got the mean of 3.50 with a standard deviation of 0.11 . Therefore, the F-value was 3.38, while the significance value was 0.00 , which does not exceed the 0.05 level of significance. Thus, the null hypothesis was rejected and found to be significant.

In terms of "Procedures," School heads obtained the mean of 3.72 with a standard deviation of 0.08 , while teachers got the mean of 3.54 with a standard deviation of 0.17 . Therefore, the F-value was 3.11 while the significance value was 0.00 , which does not exceed the 0.05 level of significance; thus, the null hypothesis was rejected and found to be significant. In terms of "Remarks," School heads obtained the mean of 2.10 with a standard deviation of 0.10 while teachers got the mean of 1.97 with a standard deviation of 0.08 . Therefore, the F-value was 3.34 while the significance value was 0.00 , which does not exceed the 0.05 level of significance; thus, the null hypothesis was rejected and found to be significant.

In terms of "Reflection," School heads obtained the mean of 3.28 with a standard deviation of 0.05 while teachers got the mean of 3.25 with a standard deviation of 0.06 . Therefore, the F-value was 0.96 while the significance value was 0.35 , which exceeds the 0.05 level of significance; thus, the null hypothesis was accepted and found to be not significant. The data proved that school heads and teachers have different perceptions of teaching performance in lesson planning. For example, school heads believed that teachers are competent enough in writing the different parts of the lesson plan while the teachers are not sure if they are doing it correctly.

Table 9 illustrated the teaching performance in lesson planning of the teachers during the first semester as assessed by themselves regarding the subject matter with a composite mean of 2.34 verbally interpreted as "Less Serious." The highest mean obtained was 2.43 for item number 4 , "did not plan many ways to teach what it contains including standards or the essential knowledge that students need to learn" verbally interpreted as "Less Serious." The lowest mean obtained was 2.27 for item number 3, "was unable to follow curriculum guide of the learning area being taught" followed by item number 9 "did not make use of multiple resources that are available to them, including the tag and $1 \mathrm{~m}$ " both were verbally interpreted as "Less Serious."

118 Consortia Academia Publishing (A partner of Network of Professional Researchers and Educators) 
Lesson planning of the teachers and its effect on their performance in selected public elementary schools

Table 9

Teaching performance in lesson planning of the teachers during the first semester: Subject matter

\begin{tabular}{lcc}
\hline \multicolumn{1}{c}{ Subject Matter } & \multicolumn{2}{c}{ Teachers } \\
& Mean & VI \\
\hline 1. did not have a deep understanding of the curriculum. & 2.35 & LS \\
2. was helpless in striving to teach the curriculum content. & 2.38 & LS \\
3. was unable to follow the curriculum guide of the learning area being taught. & 2.27 & LS \\
4. did not plan many ways to teach what it contains, including standards or the essential knowledge & 2.43 & LS \\
students need to learn. & 2.35 & LS \\
5. lack of ability to set a long-term vision of what learners need. & 2.38 & LS \\
6. did not include performance standards, or the abilities and skills learners need to demonstrate & & LS \\
concerning their knowledge. & 2.33 & LS \\
7. was unable to demonstrate readiness to learn the curriculum standards of the next grade level. & 2.31 & LS \\
8. could not aid learners in mastering the content and competencies of the curriculum progressively. & 2.28 & LS \\
9. did not use multiple resources available to them, including the T.G. and L.M. & 2.33 & LS \\
10. was unable to plan their instruction backward by following the curriculum guide. & Composite Mean & 2.34 \\
& LS \\
\hline
\end{tabular}

\section{Table 10}

Teaching performance in lesson planning of the teachers during the first semester: Strategies

\begin{tabular}{lcc}
\hline \multicolumn{1}{c}{ Strategies } & Teachers \\
& Mean & VI \\
\hline 1. was unable to predict which part of the lesson learners learn & 2.23 & LS \\
2. did not prepare strategies that help learners learn. & 2.33 & LS \\
3. could not explore utilizing different instructional strategies that consider learners' varying characteristics. & 2.22 & LS \\
4. was unable to build learners' understanding. & 2.13 & LS \\
5. was unable to adjust instruction in response to the need of the learners. & 2.08 & LS \\
6. was unable to treat learners as active agents in their learning. & 2.16 & LS \\
7. did not show what the teacher and learners will do to understand the lesson together. & 2.11 & LS \\
8. lack of ability to demonstrate what a teacher needs to do inside the classroom. & 2.11 & LS \\
9. could not describe what learners need to do as co-constructors of knowledge inside the classroom. & 2.19 & LS \\
10. was unable to respond to learners' needs. & 2.23 & LS \\
& Composite Mean 2.18 & LS \\
\hline
\end{tabular}

Table 10 displayed the teachers' teaching performance in lesson planning during the first semester as assessed by themselves in terms of strategies wherein the composite mean obtained was 2.18 verbally interpreted as "Less Serious." The highest mean obtained was 2.33 for item 2, "did not prepare strategies that help learners learn" followed by item 1 "was able to predict which part of the lesson learners learn." Item 10 "was unable to respond to learner's need," which got the means of 2.23 verbally interpreted as "Less Serious." Furthermore, the lowest mean obtained was 2.08 for item 5, "was unable to adjust instruction in response to the learners' need," which is verbally interpreted as "Less Serious."

\section{Table 11}

Teaching performance in lesson planning of the teachers during the first semester: Assessment

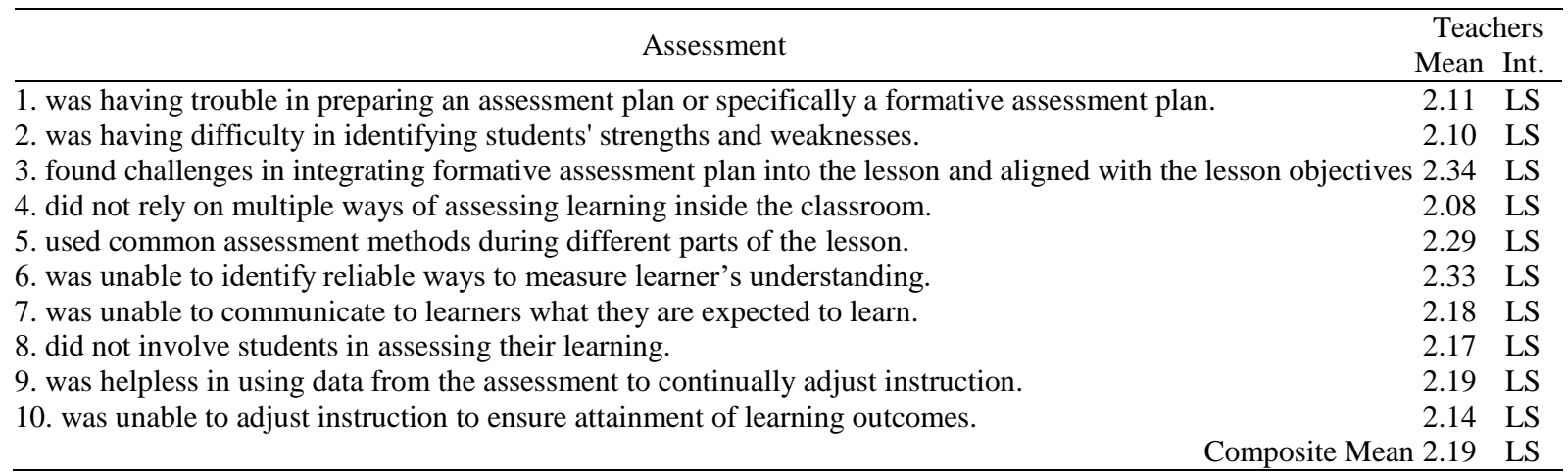

Table 11 determined that teaching performance in lesson planning of the teachers during the first semester as 
Rojo, M.

assessed by themselves in terms of assessment with composite mean of 2.19 verbally interpreted as "Less Serious." The highest obtained mean 2.34 for item 3 "found challenges in integrating formative assessment plan into the lesson and aligned with the lesson objectives" followed by 2.33 for item 6 "was unable to identify reliable ways to measure learner's understanding" both were interpreted as "Less Serious." Furthermore, the lowest obtained mean was 2.08 for item 4, "did not rely on multiple ways of assessing learning inside the classroom," verbally interpreted as "Less Serious."

Table 12

Teaching performance in lesson planning of the teachers during the first semester

\begin{tabular}{lccc}
\hline \multicolumn{1}{c}{ Aspects } & Mean & VI \\
\hline Objectives & & 2.34 & LS \\
Strategies & & 2.18 & LS \\
Assessment & & 2.19 & LS \\
& \multirow{2}{*}{ Composite Mean } & 2.24 & LS \\
\hline
\end{tabular}

As reflected from the table, the teachers' teaching performance in lesson planning during the first semester assessed by themselves in terms of different aspects obtained the composite mean of 2.24 verbally interpreted as "Less Serious." Furthermore, the objective, strategies, and assessment got the means of 2.34, 2.18, and 2.19, respectively, all were interpreted as "Less Serious." It means that the teachers identified problems in writing objectives, choosing strategies, and assessing the learners' performance. These problems shall be addressed immediately to the instructional needs of the learners since they are the most important aspect of the teaching-learning process.

\section{Recommendations}

Based on the results of the study, the following finding is at this moment summarized:

$>\quad$ The teaching performance in lesson planning of the teachers during the first semester as assessed by the two groups of respondents concerning different variables revealed that the overall composite means obtained 3.37 and 3.23 for school heads and teachers, respectively, both interpreted as "Competent" with the total of 3.25 verbally interpreted as "Competent."

$>\quad$ The significant difference between the assessments of the two groups of respondents on the teaching performance in lesson planning of the teachers concerning different variables such as "Objectives," "Contents," "Learning Resources," "Procedures," and "Remarks" revealed that the obtained values were $0.04,0.00,0.00,0.00$, and 0.00 . Therefore, respectively, which do not exceed the 0.05 level of significance, the null hypothesis states that there is no significant difference between the assessment of the two groups of respondents on the teaching performance in lesson planning of teachers was Rejected and found to be Significant. Furthermore, "Reflection" obtained a value of 0.35, which is greater than the 0.05 level of significance. Thus hypothesis is Accepted and found to be Not Significant.

$>\quad$ The teaching performance in lesson planning of the teachers during the first semester assessed by themselves in different aspects shows that the obtained composite mean 2.24 verbally interpreted as "Less Serious." Furthermore, the objective, strategies, and assessment got the means of 2.34, 2.18, and 2.19 , respectively, all were interpreted as "Less Serious."

From the conclusions drawn, the following recommendations are at this moment offered:

$>$ Teachers may revisit their teaching strategies, teaching methods, and techniques for a better outcome. Their knowledge may be enhanced or developed when the identified problems will be properly addressed. 
Lesson planning of the teachers and its effect on their performance in selected public elementary schools

$>\quad$ The teachers shall be trained in lesson planning to be empowered to carry out quality instruction.

$>\quad$ The problems identified shall be addressed immediately to the instructional needs of the learners since they are the most important aspect of the teaching-learning process.

$>\quad$ School Heads and teachers may explore and utilize different instructional strategies that consider learner's varying characteristics. They may rely on multiple ways of assessing learning inside the classroom as well.

$>\quad$ The proposed action plan may be adapted to capacitate teachers.

$>\quad$ A similar study may be undertaken from a wider perspective considering different variables.

\section{Conclusions}

Based on the findings of the study, the following conclusions have been made:

The teachers are equipped with the necessary knowledge in lesson planning. However, some aspects still need to be improved. The school heads and teachers have different perceptions on the teaching performance in lesson planning of teachers. For example, school heads believed that teachers are competent enough in writing the different parts of the lesson plan while the teachers are not sure if they are doing it correctly. The teachers identified minor problems in writing objectives, choosing strategies, and assessing the learners' performance.

Acknowledgments - The researcher would like to extend the sincerest gratitude to all the people who helped and shared the effort and knowledge to make this research a reality. She would like to express her gratefulness to her adviser Dr. Emma A. Dimitui, for the continuous support of her research, for her patience, motivation, enthusiasm, and immense knowledge. Furthermore, I could not imagine having a better adviser and mentor for my research study, to her very humble professor Dr. Marichu C. Sta. Ana, for her guidance, helps her all the time of research and writing of this research. She would like to give the deepest gratitude to the Dean of Graduate School in Emilio Aguinaldo College, Dr. Lino C. Reynoso, who is the key person in the realization of this study. Furthermore, to her mentors and panelist, she truly salutes their expertise to surmount what seems to be an uphill task. Finally, to all her respondents, school heads, and teachers, thank you for the time, suggestion, and encouragement to get the necessary information to make this thesis possible. To all her friends, thank you for your understanding and encouragement in many moments. Your friendship makes her life a wonderful experience. Unfortunately, she cannot list all that names here, but you are always on her mind. Thank you, Lord, for always being there for her, giving them the knowledge and wisdom, in exploring things, for the guidance in helping surpass all the trials that she encountered, and for giving her determination to pursue her study.

\section{References}

Airasian, P. (2017) Enhancing learning through constructive alignment. Higher Education, 32, 347-364. https://doi.org/10.1007/BF00138871

Ang, R. (2016). Elements of student-centered learning. Retrieved from http://m.ateneo.edu/sites/default/files/Elements\%20of\%20Student\%20Centered\%20Learning_2012.pdf

Bambrick-Santoyo, P. (2018). Good coaching leads to good leadership. Phi Delta Kappan, 94(4), 70-71. https://doi.org/10.1177/003172171209400419

Begle, E. G. (2016). Critical variables in mathematics education: Findings from a survey of the empirical literature. Washington, DC: Mathematics Association of American and the National Council of Teachers of Mathematics.

Bigelow, D. N. (2017). The liberal arts and teacher education: A confrontation. Lincoln: University of Nebraska. 
Rojo, M.

Boud, A. (2016). Everyone's invited to the party: Catherine: A case study of a beginning teacher. Palo Alto, CA: Stanford University, Knowledge Growth in Teaching Project.

Bramschreiber, T. (2018). Taking peer feedback to heart. Teacher evaluation: What's fair? What's effective?

$A S C D, 70(3)$.

Carr, J. F., Fauske, J. R., \& Rushton, S. (2017). Teaching and leading from the inside out A model for reflection, exploration, and action. Thousand Oaks, CA: Corwin Press.

Dent, J. A., \& Harden, R. M. (2017). A practical guide for medical teachers. Harcourt Publishers.

Department of Education, Prince Edward Island. (2003). Guidelines for the evaluation and selection of learning resources. Charlottetown, Prince Edward Island.

Stronge, K., \& Tucker, (2018). Generating teaching effectiveness: The role of job-embedded professional learning in teacher evaluation (Research and Policy Brief). Washington, D.C.: National Comprehensive Center for Teacher Quality.

Teachers and students' academic performance. Retrieved from https://www.lsu.edu.ph/application/files/2414/6916/4485/Vol__15_No._1.pdf 